\title{
Kişisel Markalaşma Üzerine Bir Derleme Çalışması
}

\author{
DOI: 10.26466/opus.846679 \\ * \\ Melis Kaytaz Yiğit* \\ * Dr. Öğr. Üyesi, Avrasya Üniversitesi, ̇̇̈BF, Trabzon/Türkiye \\ E-Posta: meliskaytaz@gmail.com ORCID: 0000-0001-7036-166X
}

Öz

Günümüzde meydana gelen teknolojik ve toplumsal gelişmelerle birlikte, son yillarda markalarn ürünlerden, şehirlere ve üniversitelere kadar toplumun her alanında kendini göstermesi, marka kavramının hem akademik hem de işletme dünyasında önemli bir araç olarak değerlendirilmesini sağlamıştır. Her ne kadar kişisel markalaşma uzun yıllardır girişimciler, politikacılar, genel müdürler ya da işletmeler için genel bir fenomen olsa da, son on yilda, özellikle sosyal medyanın kişilerin günlük yaşamında aktif rol almasıyla birlikte, toplum içerisindeki hemen hemen her yaş, eğitim, cinsiyet grubundaki insanlar için etkili bir iletişim kurma, farkındalık ve bilinirlilik yaratma aracı haline gelmiştir. Literatür taraması olarak tasarlanan bu araştırmada, kişisel markalaşma kavramında geçmişten günümüze meydana gelen değiş̧ikliklerin ortaya konmasl, kişisel markaları oluşturan faktörler ve kişisel markaların hem geleneksel mecrada hem de online mecrada nasıl yaratılabileceği konularının incelenmesi amaçlanmıştır. Son olarak, son 10 yılda kişisel markalaşma literatüründe var olan kişisel markalaşma çalışmaları incelenmiş, kavramla ilgili ele alınmamış konular belirlenmiş ve gelecek çalışmalar için araştırma başlıkları önerilmiştir.

Anahtar Kelimeler: Marka, Kişisel marka, Kişisel markalaşma, Sosyal medya. 


\title{
A Literature Review on Personal Branding
}

\begin{abstract}
Along with the technological and social developments that have taken place today, the emergence of brands in all areas of society from products to cities ad universities in recent years has made the concept of branding an important tool both in the academic and business world. Although personal branding has been a common phenomenon for entrepreneurs, politicians, general managers, or businesses for many years, in the last decade, especially with social media taking an active role in people's daily life, it has become an effective communication tool for creating awareness and familiarity for people of almost in every age, education, gender group in society. In this study, designed as a literatüre review, it is aimed to reveal the changes in the concept of personal branding from part to present, the factors that make up a personal brand, and how to create personal brands in traditional and online channels. Finally, within the framework of personal branding studies existing in the literature in last 10 years, the topics that have not been addressed regarding the concept were determined and research titles were proposed for future studies.
\end{abstract}

Keywords: Brand, Personal brand, Personal branding, Social media 


\section{Giriş}

Küresel toplum, dünyayı daha küçük bir yer haline getiren teknolojilerin ve çevrimiçi platformların ilerlemesi ile yapılanmaktadır. Hem tüketiciler hem de işletmeler, bu gelişmeler sayesinde daha birbirine bağlantılı ve rekabetçi hale gelmeye başlamış ve bilginin anlık ve sürekli olarak dolaştığı dijital bir dünyada ayakta kalmaya çalışmaktadırlar (Kang, 2013; Olins, 2009). Rekabetin hem kişisel hem de işletme düzeyinde küresel hale gelmesi, kurum ve kişilerin rakiplerinden farklılaşmasını dolayısıyla markalaşmanın gerekliliğini öne çıkarmaktadır (Vitalar, 2019).

Kişisel markalaşma, genellikle kişinin halkın kendisini algılama şeklini kontrol etmeye çalışmasıdır. Bu nedenle kişisel markalaşma, yaratıcılık, hayırseverlik, sıcaklık, kadının gücü, özel yetenekler, nezaket, şefkat gibi imajları aşılayabilir ve bu alanlara ilgi duyma tutkusu yaratabilir (Hood vd., 2015). Kişisel markalaşma, bireyin kendi markasının pazarlamacısı ve kendi şirketlerinin CEO'ları olduğunu vurgulayan Tom Peters (1997) tarafından ortaya atılan bir pazarlama iletişimi biçimidir. Kavram, kişinin bir iş adayı olarak pozitif bir profil oluşturmasını, özellikle beklenti, hedef ve değerlerini iletmesini sağlayan stratejik bir pazarlama kavramıdır (Ollington vd., 2013; Machaz ve Shokoof, 2016).

Öte yandan sosyal medya olgusunun hızla yaygınlaşmasıyla tüketiciden tüketiciye yönlendirilen bilgi, kişisel farkındalık yaratmada, güvenilirlik oluşturmada, kişisel farklılaşmayı teşvik etmede ve kişisel markalaşma potansiyelini yönetmede önemli bir rol haline gelmiştir (Vitberg, 2010; Chen, 2013). Bir zamanlar sadece işletmeler siyasetçiler, ünlüler ve liderler için bir strateji olarak kabul edilen çevrimiçi araçlar, günümüzde kişisel markalaşmanın tüketiciler için önemli bir pazarlama görevi haline gelmesine izin vermiştir (Chen, 2013; Shepherd, 2005). Bunların yanında, örgütsel ve mesleki çalışma alanlarında da karşımıza çıkan kişisel markalaşma kavramı, kişinin kariyer stratejisinde kendini diğerlerinden farklılaştırması, daha stratejik davranması ve teknoloji kullanımıyla kendi markasını geliştirmesi açısından da etkili bir yoldur.

$\mathrm{Bu}$ çalışmada kişisel markalaşma kavramının geçmişten günümüze gelişimini incelemek amacıyla bir literatür taraması yapılmıştır. Bu amaç doğrultusunda ilk olarak, kişisel markalaşma kavramının tanımı ve tanımda meydana gelen değişiklikler incelenmiştir. Daha sonra kişisel 
markaları oluşturan temel bileşenler literatürdeki önemli çalışmalarla ortaya konmuş ve yıllar içerisinde tanımın gelişmesi ile beraber yazarlar tarafından belirlenen kişisel markalaşma süreçlerine değinilmiştir. Son olarak, son 10 yıllık incelenen kişisel markalaşma çalışmalarına yer verilerek, literatürdeki araştırma boşlukları belirlenmiş ve konuyla ilgili çalışmak isteyen araştırmacılara gelecek araştırma önerilerinde bulunulmuştur.

\section{Kişisel Markalaşma Kavramı}

Kişisel markalaşmanın kökeninin markalaşmaya dayanması sebebiyle, marka ve markalaşma konusundaki köklü literatürü incelemek, kişisel markalama kavramını ve özelliklerini anlamak için temel bir yoldur. Markalaşmanın tarihi Amerika Birleşik Devletleri'nin batısında 1800'lerde çiftçilerin hırsızları engellemek ve kayıp hayvanların tespit etmek için hayvanları ayırt edici sembollerle işaretlemesiyle başlamıştır. Tüketici markalaması ise on dokuzuncu yüzyılın sonlarında başlamış ve 1920-1970 yılları arasında zirve dönemini yaşamıştır. Marka, ürünleri tüketicilere benzersiz avantajlar sağlayan ve bir ürünü diğerlerinden ayıran isimdir (Philbrick ve Cleveland, 2015). Literatürde markalaşmanın temelini oluşturan Aaker (1991), Kotler ve Armstrong (2012) gibi yazarlar, markaların ürünlerin kalitesini yansıtarak tüketicileri satın alma karar süreçlerinde destelemeleri gerektiğini savunmaktadırlar. Aaker'a göre (1997) markayla ilişkilendirilen insani özellikler olarak tanımlanan marka kişiliği kavramı, markalaşmada oldukça hayati bir yere sahiptir. Kapferer (2004) tarafından tüketici deneyimlerinin toplamı olarak tanımlanan markalaşma da uyumlu ve tutarlı bir kişisel özellik kurmak, ürünü, hizmeti, şirketi hatta kişinin imajını geliştirmesinde önemlidir. Bu anlamda, Aaker (1991), Kapferer (1997) ve Keller ve Richey (2006) marka kavramı tartışmalarının içerisinde psikolojik çağrışımlarının dâhil edilmesi gerektiğini öne sürmüşlerdir (Vitalar, 2019).

Tüketici markasının doğal bir uzantısı olarak ele alınan kişisel markalaşmayı ürün ya da şirket markalarından ayıran en temel fark, ürün ya da şirket markaları talep üzerine yaratılırken, kişisel markaların kişinin gelişimi boyunca formüle edilmesidir (Rangarajan vd., 2017). Bunun yanı sıra kişisel markalar, ürün markalarına göre daha odaklı olabilirler; bir 
satış elemanı belirli sektördeki belirli işletme seviyesindeki müşteri grubunu hedeflemek için bir marka geliştirilebilirken, ürün markası hissedarlarla, çalışanlarla ve potansiyel çalışanlarla iletişim kurmalıdır. Öte yandan, kişisel markanın zaman içinde değişmesi ürün markasına göre çok daha kolaydır; örgütsel basamakları yükseltme umuduyla geliştirilebilir (Rangarajan vd., 2017).

Genel olarak literatürde kişisel markalama kavramının ilk kez 1997 yılında Tom Peter'sın "Sizi Arayan Marka" başlıklı makalesinde ortaya atıldığ Gofman tarafından 1959 yılında yayınlanan "Günlük Yaşamda Benliğin Sunumu" adlı kitabında dolaylı olarak tanıtılmıştır. Her iki çalışma arasında geçen kırk yıl içerisinde, toplumda kişisel markalaşma kavramının gelişmesine yol açan temelde üç değişiklik meydana gelmiştir. 1970'lerde büyük şirketlerde yapılan geniş çaplı işten çıkarmaların olduğu yıllarda meydana gelen ilk toplumsal değişiklik, söz konusu işten çıkarmaların bireylere artık işverenlerin kendileri için ömür boyu istihdamı sağlamadığını ve kişisel ekonomik garantörleri olmadığını göstermiştir. İkinci değişiklik ise toplumun, çalışmanın kişisel tatmin ve anlam kaynağı olabileceğine dair yeni fikrinin oluşmasıyla meydana gelirken, üçüncü değişiklik gelişen teknoloji ve iletişim kurma becerisiyle bireylerin kişisel fikirlerini değişik online araçlar kullanarak paylaşmaya başlamasıyla oluşmuştur (Philbrick ve Cleveland, 2015).

Tom Peters (1997) tarafından ortaya konan kişisel markalaşmanın özünde, planlı bir kendi kendini pazarlama süreci yer almaktadır (Karaduman, 2013; Khedher, 2014). Başlangiçta sadece ünlüler, politikacılar, iş liderleri gibi kişiler için geçerli olan kişisel markalaşma, zamanla iş gücü piyasası, bilim adamları, gelecekte iş piyasasına girecek olan öğrenciler ve hatta tüm sosyal medyada faaliyet gösteren meslek grupları için önemli olduğu ortaya çıkmıştır (Kucharska, 2017).

Kişisel markalaşma ifadesi daha sonra Lair, Sulliven ve Cheney (2005) tarafından kişinin "kendi kendini ambalajlaması" ve "dijital marka ile ilgili kamuoyunu olumlu etkileme yeteneği" olduğu öne sürülmüştür. Böylece yazarlar günümüz kişisel markalaşma kavramının, daha önce kişisel gelişim kitaplarında yer alan kişisel markalaşma terimin modern evrimi olduğu ifade etmişlerdir (Machaz ve Shokoof,2016). Öte yandan kişisel markalaşma, pazarlama, kişisel satış ve imajla eş anlamlı değildir, 
çünkü kişisel markalaşma, kişinin profesyonel tatmini ve başarısında etkili olan bugüne kadarki kendisiyle ilgili en derin gerçek ve ikna edici yönünü stratejik olarak bir araya getirmesidir (Philbrick ve Cleveland, 2015).

Ortaya konulan kişisel markalaşma kavramlarının ortak bir teması vardır: algı. Rampersad'a göre (2006), benlik saygısı kişinin kendini nasıl algıladığıyla ilgilidir ve kişisel markalaşma başkalarının kişiyi nasıl algıladığıyla ilgilidir. Kişiler farkında olsalar da olmasalar da, herkesin bir kişisel markası vardır ve bu kişinin başkaları tarafından nasıl göründüğüyle ilgilidir. Kişi, kendi markasını stratejik, tutarlı ve etkili bir şekilde yöneterek başkalarının kendisi hakkında sahip olduğu algıyı değiştirebilir. Kişisel marka, kişisel markanın kombinasyonu olarak tanımlanabilir. Bu kombinasyona eklenen özellikler, değerler, itici güçler, güçlü yönler ve tutkular, kişinin benzersiz değer vaadini oluşturur ve kişiyi diğer kişilerden ayırır. Daha basit bir ifadeyle kişisel bir marka, ister bir iş ortamı, ister akademik bir alan veya girişimcilikle ilgili bir ortam olsun, kişinin çevresindeki dünyada kim olduğunu tanımlar, açığa kavuşturur ve iletir (Philbrick ve Cleveland, 2015).

Sadece iş hayatında değil günlük yaşamda da markalaşma, pazarlama ve satıştan daha güçlü, etkili ve sürdürülebilir bir olgu olmasının yanı sıra, rakiplerin ortadan kaldırılmasında da oldukça etkilidir. Kavram, belirli alg1 ve duygularla ilişkilendirilen bir marka kimliği oluşturarak başkalarını etkilemekle bağlantılıdır. Günümüzde markalaşma kavramı artık sadece şirketler için değil kişiler için de önemli bir trend haline gelmiştir. Özetle, başarılı kişisel markalaşma, algıların etkili bir şekilde yönetilerek, başkalarının söz konusu kişiyi nasıl algıladığını ve düşündügünü kontrol etmeyi ve etkilemeyi gerektirmektedir. Günümüzün online, sanal ve bireysel çağında, güçlü kişisel bir markaya sahip olmak, kişinin kendini konumlandırma stratejisi için daha önemli hale gelmiştir (Rampersad, 2008).

Kişisel performans sergileyebilme olanağı tanıması ve kişisel bir markayı rakiplerinden ayırmaya yardımcı olacak bireysellik duygusu sunuyor olması, kişisel markalaşmayı sosyal medyadaki amatör bireyler için önemli bir iş kavramına dönüştürmüştür. Her kişisel markanın kendi kişiliği ve benzersizliği olduğundan kişisel markalar kişinin temel karak- 
terini yansıtmaktadır. Shuker (2010) kişisel markalaşmayı bir sanata benzeterek, kişilerin başkaları üzerinde arzulanan etkiyi yansıtmasını amaçlayan bir dizi etki yönetimi ve stratejik uygulama olduğunu ve genellikle kişiler arası sosyal ilişki alışverişi ile sonuçlandığını ileri sürmektedir (Chen, 2013).

\section{Güçlü Kişisel Markalar Bileşenleri}

Litertatürde başarılı bir kişisel marka yaratmak için başarılı bir işletme markasının nasıl çalıştığına bakmak gerektiğinden bahsedilmektedir; çünkü yıllar boyunca iş dünyasında geliştirilen ve başarıyla kullanılan ilkeler ve fikirler kişisel bir marka oluşturmaya kolayca uyarlanabilir (McNally ve Speak, 2009).

Kişisel markalaşma kişinin imajı ve itibarıyla ilgili olmasının yanında çevreyi etkilemenin, gelecek fırsatların ve yükselişin anahtarıdır (Kang, 2013). Yapılan araştırmalar (Johnson, 2019; Kang, 2013; Farhana, 2012; Harris ve Rae, 2011) güçlü bir kişisel marka oluşturmak için bir bireyin kendi markasına rehberlik edecek strateji ve eylemleri geliştirmesi gerektiğini göstermektedir. Kimi uzmanlar (Harris ve Rae, 2011; Liu ve Suh, 2017) güçlü bir markanın özgünlük olmadan var olamayacağını vurgularken, kimileri ise (Baltezarević ve Milovanovic, 2014) güçlü bir marka için liderlik becerilerinin gerekli olduğunu savunmaktadır. Öte yandan, kişisel markalaşmada bireyin geçmişi, benimsediği felsefe, yaşam tarzı ve tutkuları kişisel marka niteliklerini oluşturmada son derece önemlidir (Wilson ve Blumenthal, 2008). Bununla birlikte, Kotler ve Armstrong'un (2012) belirttiği gibi markalar isim ve sembollerden çok daha fazlasıdır ve güçlü bir marka, yüksek bir marka değerine sahip olmalıdır (Vitalar, 2019).

Montoya ve Vandehey'e (2005) ve Rampersad'a (2006) göre, sürdürülebilir, özgün, tutarlı ve akılda kalıcı bir kişisel markalaşma aşağıda yer alan bazı önemli kriterlere dayanmaktadır. Kişi kendini bu kriterlere göre markalaştırdığında ve bunlara göre hareket edeceğine garanti verdiğinde, markası güçlü hale gelecek ve kişi kendini başkalarından ayrıştırarak hedef kitlesi tarafından daha iyi anlaşır duruma gelecektir. Özgün kişisel marka oluşturmak kişinin hayallerine, vizyonuna, misyonuna, yaşam felsefesine, değerlerine, kimliğine ve öz farkındalığına dayanan, özgün 
benliğinde kim olduğunu belirlemekle başlamaktadır (Rampersad, 2008). Söz konusu kriterler şunlardan oluşmaktadır:

- Özgünlük: Kişisel marka kişinin gerçek kişiliği üzerine inşa edilmelidir. Kişinin karakterini, davranışlarını, değerlerini ve vizyonunu yansıtmalıdır; bu sebeple de kişisel hırsla uyumlu olmalidir.

- Bütünlük: Kişisel markalaşma kişi, kişisel hırsı tarafından belirlenen ahlaki ve davranışsal kurallara uymalıdır.

- Tutarlılık: Kişisel markalaşmada kişi davranışlarında tutarlı olmalı, başkalarına karşı her zaman güven verici olmalıdır.

- Uzmanlık: Kişisel markalaşmada bir uzmanlık alanına odaklanılmalı, tek ve temel bir yeteneğe ya da benzersiz bir beceriye konsantre olarak diğerlerinden farklı ve özel hale gelinmelidir.

- Yetki: Kişisel markalaşmada kişi, belirli bir alanda bir tanınmış bir uzman olarak görülmeli, son dereceli yetenekli, son derece deneyimli ve etkili bir lider olarak algılanmalıdır.

- Farklılık: Kişi, rakiplerden farklı ve başkalarına benzersiz değer katacak şekilde markasını farklılaştırmalıdır

- Illgili: Kişinin markasında savunduğu şey, hedef kitlenin önemli olduğunu düşündüğü şeyle bağlantılı olmalıdır.

- Görünürlük: Kişisel marka izleyicinin zihnine yerleşene kadar sürekli, tutarlı ve tekrar tekrar yayınlanmalıdır. Tekrar edilerek, hedef kitle markaya uzun vadeli maruz bırakılmalıdır.

- Kalıcılık: Bir markanın büyümesi için zaman ihtiyacı olduğu akıldan çıkarılmamalı, pes edilmemeli ve kişi kendine inanıp, sabırlı olmalidir.

- İyi niyet: Kişi, olumlu ve değerli olarak kabul edilen bir değerle ilişkilendirilmelidir.

- Verim: Performans kişisel markanın bilinir hale gelmesinden sonraki en önemli unsurdur. Kişi sürekli kendini geliştirerek performans sergilemeli ve bunu Kişisel Dengeli Puan Kartına (Balanced Scorecard) transfer etmelidir.

Öte yandan McNally ve Speak'e (2009) göre bir markanın gücünü belirleyen üç bileşen vardır: ayırt edici olmak, alakalı olmak ve tutarlı olmak. Ayırt edici olmak, sadece farklı olmanın çok ötesinde bir anlam taşımaktadır. Marka oluşturma sadece bir imaj oluşturma değildir, diğerlerinin 
ihtiyaçlarını iyi anlamak, bu ihtiyaçları karşılamak istemek ve değerlerinize uygun şekilde davranmak sonucunda meydana gelmektedir. Kişinin değerleri sadece kişinin ne düşündügünü değil aynı zamanda nasıl davrandığını da etkilemektedir. Bu yüzden kişisinin değerleri üzerinden nasıl davrandığı onu diğerlerinden farklılaştırmaktadır. İnsanlar birbirlerinin davranışını gözlemler ve davranışların neden yapılıp yapılmadığıyla ilgili yargılarda bulunurlar ve söz konusu yargılar zamanla kişinin diğerleri tarafından nasıl algılandığını ortaya koyar. Başka bir ifade ile kişisel markalar dayandıkları değerlerden ödün vermeden başkalarının ihtiyaçlarını karşılamaya odaklandıklarında kişilerle bağlantı kurar ve güçlenir. Belirgin bir şekilde kişinin kendini oluşturan değer ve fikirlerin yansıması olduğundan kalıcı bir ilişki kurulabilir (McNally ve Speak, 2009).

Bununla birlikte başka kişiler için önemli olan tek şey farklı olmak değildir; kişinin savunduğu şeyin başkalarıyla alakalı olması gerekir. Kişisel markalaşma oluşumunda kişi başkası için önemli olanın kendisi için önemli olduğunu her gösterdiğinde güç kazanmaktadır. Yazarlara göre hem ayırt edici hem de alakalı olmanın sinerjik etkisi, kişisel bir markanın gücünü ortaya koyar. Alaka düzeyi oluşturmak için başkalarının ihtiyaç ve ilgi alanlarını doğru belirleyerek, söz konusu ihtiyaç ve ilgi alanlarını kişisel güçlü yön ve yeteneklerle ilişkilendirmek gerekmektedir ve bu bir süreçtir (McNally ve Speak, 2009).

Güçlü bir kişisel marka oluşturmanın üçüncü bileşeni, hem ayırt edici hem de alakalı şeyleri tekrar tekrar yapmak anlamına gelen tutarlılıktır. Tüm güçlü markların ayırt edici özelliği olan tutarlılık, kişilerin başkaları tarafından kabul edilme veya tanınmasını sağlar. Öte yandan ilişkideki tutarlılık, davranışın güvenilirliği ile sağlanmaktadır. Tutarlı ve güvenilir davranışlar beraberinde güven getirir. Her seferinde hedef kitlenin beklediği şekilde davranmak kişisel markanın gücünü pekiştirmektedir (McNally ve Speak, 2009).

Özetle, başarılı kişisel markalaşma, algıları etkili bir şekilde yönetmeyi ve başkalarının kişiyi nasıl algıladığını ve nasıl düşündüğünü kontrol etmeyi ve etkilemeyi gerektirmektedir. Günümüz çevrimiçi, sanal ve bireysel çağda güçlü bir kişisel markaya sahip olmak, kişisel başarının anahtarı olması açısından önemli bir konudur. Kişisel marka, kişinin adının 
görüldüğünde başkalarının zihninde yaratılan tüm beklenti, imaj ve algıların sentezinden oluşmaktadır (Machaz ve Shokoof,2016).

\section{Kişisel Bir Marka Nasıl Yaratılır?}

Literatürde son on yılda kişisel markalaşmanın nasıl oluşturulacağına dair çeşitli süreç ve aşamalar önerilmiştir. Her bir önerilen kişisel markalaşma aşamasının her ne kadar kendine has farklı boyutları olsa da temelinde aynı mantığı barındırdığı görülmektedir. Öte yandan, yıllar içerisinde sosyal medyanın kişisel markalaşmada önemli bir görevi olduğunun kabul edilmesiyle birlikte, kişisel markalaşma literatüründe sosyal medya mecrasında kişisel markalaşma aşamaları da yazarlar tarafından tanımlanmıştır.

McNally ve Speak'e göre kişisel markalaşama üç adımdan oluşmaktadır: (1) kişinin yeterliliklerin önemli olduğu alanları belirlemesi, (2) kişinin kendi standartlarını ve değerlerini incelemesi ve (3) kişinin kendi tarzını belirlemesi. Önerilen kişisel markalaşma aşamasının ilk aşamasında kişi kişisel markasının test edileceği önemli ilişkilerindeki (ör. arkadaşlık, ebeveynlik vb.) rolünü belirlemelidir. Kişi en iyi performans gösterdiği durumları gözden geçirmesi sonucunda, bir sonraki aşamada, kendisinin sürekli olarak öne çıkan üç ila beş özelliği yansıtan marka standartlarını oluşturmalı ve son aşamada kişi diğerleri ile olan ilişkilerinde etki yaratan en benzersiz kişilik özeliğini göz önünde bulundurarak tarzını belirlemelidir (Wee ve Brooks, 2010).

Yazarlara göre, söz konusu üç kişisel markalaşma adımı, kişinin hayatındaki rolleri tanımlayarak, hedef kitle ile olan ilişkisinde hangi rolün daha önemli olduğuna dair bir fikir sahibi olmasına yardımcı olur. Bununla birlikte, her bir adımda kişi sürekli sergilediği sabit özelliklerinin listesini oluşturur ve böylece kendi benzersiz özelliklerini tanımlar. Güçlü bir kişisel marka yaratmak için, kişinin önce kendisini özgün ve değerli görmesi gerektiğini vurgulayan yazarlar, kişilerarası etkileşimde akılda kalıcılığın da altını çizmekte ve kişinin hayatındaki diğer kişilerle olan ilişkilerini bilinçli, tutarlı bir şekilde yönetmesinin istikarar duygusunun gelişmesine ve bunun da kişisel markanın akılda kalma ve ayırt edilme özelliğinin oluşmasına yardımcı olduklarını belirtmektedirler. Öte yandan, McNally ve Speak (2002) işletme markası gibi kişisel markaların da 
örtük bir marka vaadi içermesi ve belirli bir zamanda belirli bir kişinin ihtiyaç ve arzusunu karşılama yeteneğini yansıtması gerektiğinin altını çizmektedirler. Yazarlara göre, kişisel bir ilişki ilk kez bir başkası için değer sağladığında marka değeri birikmeye başlar ve ilişki, markalı bir ilişkiye dönüşür (Wee ve Brooks, 2010).

2008 yılına gelindiğinde Rampersad özgün kişisel markalaşmanın 4 aşaması olduğunu belirtmiştir: (1) Kişisel hırsları tanımlamak ve formüle etmek, (2) kişisel markayı tanımlamak ve formüle etmek, (3) kişisel dengeli karneyi (Personal Brand Scorecard) oluşturmak ve (4) kişisel hırsları, markayı ve denge karnesini uygulamak ve geliştirmek (Bkz. Şekil 1) (Rampersad, 2008).

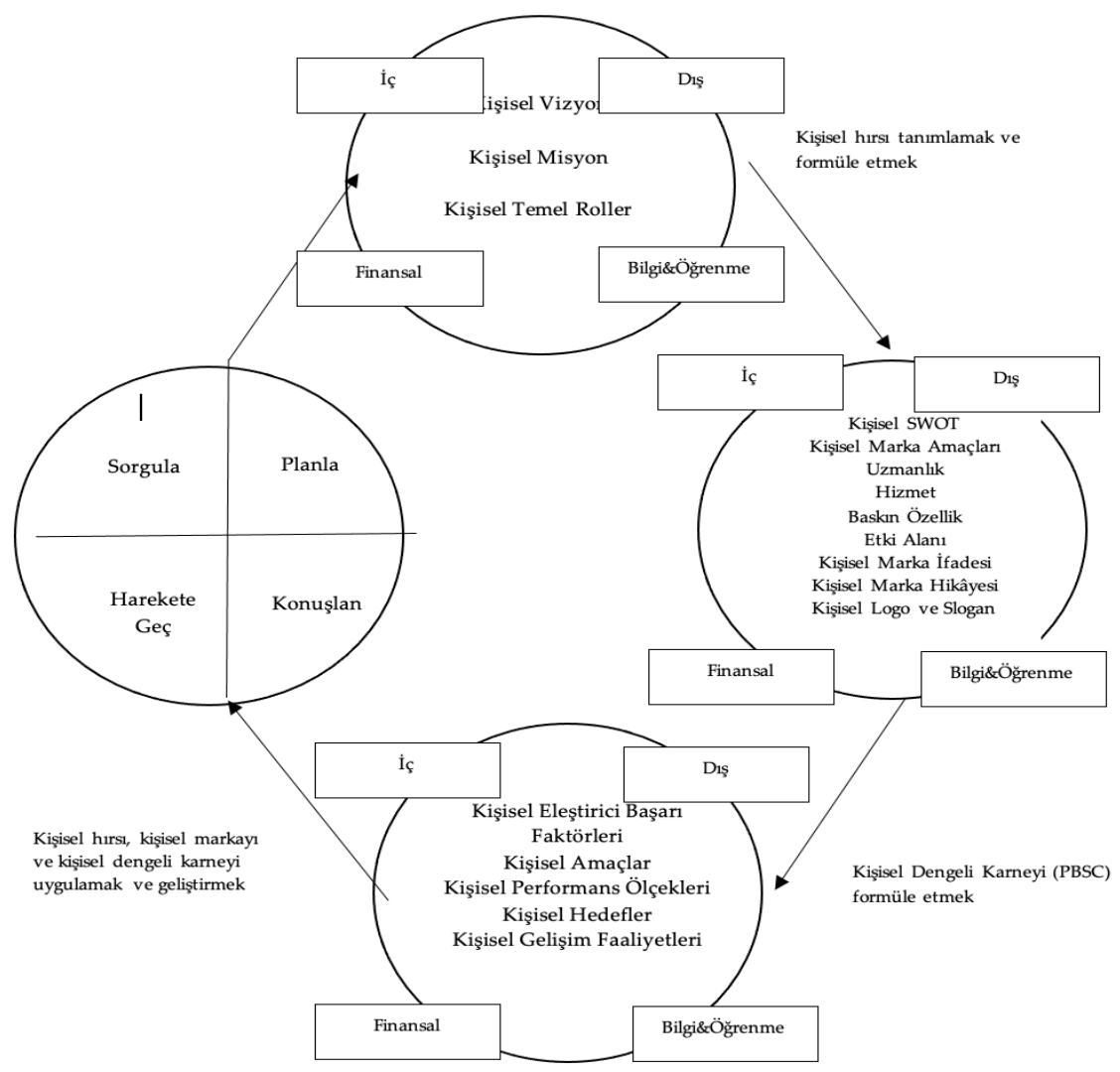

Şekil 1. Özgün Kişisel Markalaşma Modeli .

Kaynak: Rampersad, H.K. (2008). Authentic Personal Branding. www.brandchannel.com, New York. 
İlk aşama olan kişisel hırların tanımlanması ve formüle edilmesi aşaması, kişinin kişisel hırlarını heyecan verici ve ikna edici bir şekilde tamlamasını, formüle etmesini ve görünür kılmasını içermektedir. Bu aşamada kişi, kendini tanımlamalı, hayallerinin ne olduğunu, neyi temsil ettiğini, hangi özelliklerinin onu benzersiz ve özel kıldığını, neden diğerlerinden farklı olduğunu açıkça tanımlamalıdır. Kişisel markayı tanımlama ve formüle etme aşamasında ise, kişi kendi markası için uyguladığ ${ }_{1}$ SWOT analizi neticesinde özgün, ayrıt edici, alakalı, tutarlı, anlamlı ve ikna edici bir marka sözü tanımlamalı ve kendi davranış ve eylemlerinin odak noktasında bunu uygulamalıdır. Marka sözü tanımlanırken, kişi temel uzmanlığını belirleyerek tek bir temel yeteneğe odaklanması gerekmektedir. Kişisel markanın başarmak istediği temel şey belirlenirken iç, dış, bilgiveöğrenme ve finansal perspektifler göz önünde bulundurulmalıdır. Kişi kendi temel özeliklerini, en lider ve güçlü özelliklerini belirledikten sonra, hedef kitle tanımlanması ve hedef kitlenin en büyük ihtiyaçlarının neler olduğu belirlemelidir. Daha sonra, söz konusu kitle üzerinde olumlu bir tepki yaratmak için kişisel marka hakkında söylenmek istenen kişisel marka hikayesi tanımlanmalı ve kişisel markayı temsil eden kişisel logo tasarlanmalıdır (Rampersad, 2008).

Üçüncü aşama olan kişisel dengeli karne oluşturma aşaması bir önceki aşamalarda tanımlanan kişisel marka ve tutkunun gerçeğe dönüştürmek üzere harekete geçildiği, kişinin hırsına ve markasına dayalı entegre ve dengeli bir eylem planı geliştirdiği aşamadır. Kişisel dengeli karne uygulamasıyla birlikte, kişi kendi hırslarını, markasını bütünsel ve dengeli bir şekilde yönetebilir ve bunları ölçülebilir kişisel hedeflere ve iyileştirme eylemlerine çevirebilir. Kişisel marka ilerlemesinin izlenmesi yoluyla, temel marka bilgileri kaydedilir, yeni kariyer yolları tanımlanır ve kişi bir iletişim ağı oluşturmak için temel başarılarını ölçebilir ve raporlayabilir. Son aşama ise kişinin hırsını, markasını ve kişisel dengeli karnesini etkili bir şekilde uygulaması, sürdürmesi ve geliştirmesiyle ilgilidir. Kişi bu aşamada kendi markasını tutkuyla ifade etmeli, değişime bağlı olmalı, pazarda algılanan değerini sürekli olarak değiştirmeli, güven oluşturmalıdır. İletişim mecralarında tutarlı mesajlar vererek, kişileri bilinçlendirerek ve güçlü bir ilişki ağı kurarak performansını sürekli iyileştirerek ilerlemelidir (Rampersad, 2008). 
Yazar bu süreçte kişisel marka yaratmak isteyen bireylere, marka bilinirliklerini kademeli olarak büyütmek için Planla-Konuşlan-Harekete GeçSorgula adlı, sürekli takip edilmesi gereken bir öğrenme döngüsü kurgulamıştır. Döngünün uygulanması yoluyla kişisel hırs, kişisel marka ve kişisel özgün marka planlamasına uygun yaşamak, öz farkındalık, neşe, öz saygı ve mutluluğa doğru bir yolcukla sonuçlanmaktadır. Kişi, kişisel markası ilerledikçe hangi parçaların işe yarayıp hangilerinin işe yaramadığını bulmaya ve gerektiği şekilde düzeltmeler yapmalıdır. Markanın güçlenmesi, sürdürülebilmesi ve geliştirilmesi için, yeni iş görü ve deneyimlerle marka vaadi sürekli iyileştirilmeli, söz konusu boşlukları tamamlayacak rakiplerin oluşması önlenmelidir (Rampersad, 2008).

Sosyal medyada kişisel marka geliştirmek günümüzde hızla büyüyen bir trend haline gelmiştir. Günümüzde insanlar sosyal medyayı kişisel markalarını yaratmak için aktif olarak kullanmakta (Labrecque vd., 2011) ve kişilerin kişiliğinin öz ifade etmesinde etkili bir yol olarak karşımıza çıkmaktadır (Orehek ve Human, 2017). Bu sebeple, literatürde son yıllarda ele alınan kişisel markalaşama aşamalarıyla ilgili çalışmalarda sosyal medyanın kullanımına da önem verilmeye başlanmıştır.

Philbrick ve Cleveland'in 2015 yılında ele aldıkları çalışmalarında kişisel marka yaratmanın altı aşamadan oluştuğunu öne sürülmektedir: (1) iç gözlem yapmak, (2) hâlihazırda var olan markayı anlamak, (3) kişisel marka mantrasını geliştirmek, (4) fiziksel ayak izini oluşturmak, (5) dijital ayak izini oluşturmak ve (6) mesajları iletmek.

İç gözlem olan kişisel markalaşmanın ilk adımında kişi kendi içine dönerek değerlerim neler? Hayatın anlamını nasıl ve nerede bulabilirim? Tutkulu olduğum şey nedir? Kendi alanım içinde ve dişında beni başlarından ayıran özellikler nelerdir? En etkili şekilde hangi ortamlarda çalışabilirim? gibi soruları sormalı ve kendisi için bir SWOT analizi yapmalıdır. Kişinin kendi güçlü ve zayıf yönlerini belirlemesi, potansiyel işvereni için değerini anlamasına yardımcı olurken, tehdit ve fırsatları belirlemek kişinin kariyer yolunda nelerle karşı karşıya olduğunu görmesine yardımcı olmaktadır. Önerilen ikinci markalaşma adımı kişinin zaten var olan kendi markasının oluşabileceğini anlamasına dayanmaktadır. Kişi mevcut markasını iki şekilde görebilir: (1) bildiği ya da bilmediği mevcut kişisel markasını görerek, (2) kendi meslek markasını görerek. Kişi mevcut web ağlarında kendi ilettiği mesajları görmek için bir marka 
denetimi yapmall, bu sebeple Linkedln, Facebook, Twitter ve mesleki kuruluş sitelerindeki kişisel hesaplarına ve profiline dikkatlice bakmalıdır (Philbrick ve Cleveland, 2015).

Kişisel markalaşmanın üçüncü aşaması kişisel bir marka mantrası geliştirmektir. Kişisel marka mantrası kişinin kim olduğunu, neler sunması gerektiğini açıklayan hızlı, basit ve akılda kalıcı bir ifadedir. Kişi kişisel mantrasını geliştirmek için kendi duygusal çekiciliğini, tanımını ve işlevini belirlemeli ve hepsini bir araya getirmelidir. Duygusal çekicilik, kişilikle ilgilidir ve kişi insanlara nasıl hissettirdiği ve diğerlerinin kendisini tanımlamak için hangi kelimeleri kullandığını bulmak için cevaplar aramalıdır. Kişisel mantrayı oluştururken kişinin insanlara hangi hizmeti sunması gerektiğini ve kendisi diğerlerinden farklı kılan özelliklerini bulması gerekmektedir. Tüm bu sorulara cevap bulduktan sonra oluşturulan kişisel mantra, kişinin hem fiziksel hem de dijital alanda mesajlarını iletmesine yardımcı olacak temel görevi sağlayacaktır. Önerilen bir sonraki adım kişinin görünümünü ve çalışma alanine içeren fiziksel ayak izinin oluşturulmasıdır. Kişinin havalı ve profesyonel görünmesi, kişisel markasını geliştirecektir. Bu konuda dikkat edilmesi gereken önemli nokta, kişisinin görünümü değiştikçe güncellenmesi gereken bir profesyonel fotoğrafının olması ve çalışma alanının diploma veya ödül gibi varlıklarla dekore edilerek fiziksel ayak izini daha görünür hale getirme gerekliliğidir (Philbrick ve Cleveland, 2015).

Yazarlara göre kişisel marka oluşturmanın beşinci ve en önemli aşaması, dijital ayak izini yaratmaktır. Dijital ayak izini oluştururken yapılması gereken ilk şeylerden biri, sosyal medyada kullanmak için bir marka adı bulmaktır. Marka adının okunması ve fenotik olarak yazılması kolay olması ve ideal olarak çok uzun olmaması gerekmektedir. Öte ayandan orijinal olduğundan emin olmak için arama sitelerinde ve sosyal ağlarda marka isminin aratılması önemlidir. Yazarlara göre aynı kullanıcı adının birçok farklı sosyal ă̆ ve web sitesinde kullanılması, kişinin sosyal medya markasını akıllara yerleştirmenin önemli yollarından biridir. Kişisel markalaşma da kişi marka adını oluşturduktan sonra dijital ayak izini çevrimiçi oluşturmaya başlayabilir ve mesajlarını hangi kanalları kullanarak paylaşacağına karar vermelidir. Sosyal medya kullanımı, kişisel marka oluşturmak için düşük maliyetli bir çözümdür ve kişi geniş 
bir kitleyle iletişim kurup, onlardan geri bildirim alabilir. Fakat öte yandan çevrimiçi ortamlarda bilginin kontrol edilememesi ve bilgilerin yanlış yönlendirilebilmesi, yetersiz markalama söz konusu olduğunda bir dezavantaja dönüşüp kişiyi risk altında bırakabilir. Bu aşamada kişi sadece sosyal medyada paylaştiği etkileşimin içeriğine, sıklığına ve tuttarlılığına değil aynı zamanda kendi gelişimine ve eksikliklerine de odaklanarak, periyodik mark denetimi gerçekleştirmelidir (Philbrick ve Cleveland, 2015)

Yazarların ortaya koyduğu kişisel marka oluşturmanın altıncı ve son adımı kişinin mesajlarını iletmesidir. İyi, stratejik kişisel markalaşmanın temelinin hedef kitle ile başladığ göz önünde bulundurularak, kişinin en çok etkilemek istediği kitleyi belirlemesi önemlidir. Hedef kitlenin doğru tanımlanması, marka mesajının uygun şekilde tasarlanmasına yardımcı olacak ve böylece hedef kitle ile duygusal bir bağ kurulabilecektir. Bunun yanı sıra kişisel marka mesajını iletirken açıklık, tutarlılık ve istikrar üçlüsü sürekli göz önünde bulundurulmalıdır. Kişi, kişisel markasını oluştururken net ve özgün olmalı birden fazla iletişim kanalında tutarlı ve hedef kitle tarafından her zaman görünür olmalıdır. Tüm bu aşamalar tamamlandıktan sonra kişi marka itibarının sürdürülmesine de önem vermeli ve kişi, kişisel markasının bir değer ve performans vaadi sunduğunu ve hedef kitlenin beklentisi karşılaması gerektiğini unutmamalıdır (Philbrick ve Cleveland, 2015). Tarnovskaya ise 2017 YouTuber'ların kişisel markalarını online olarak nasıl oluşturduklarını inceleyen araştırmasında kişisel markalaşma sürecinin bazen sıralı olmayıp paralel işlediği tespit etmiştir. Yapılan araştırma sonucunda kişisel markalaşa süreci kişisel marka profiline bağlılık, birden fazla sosyal medya hesabının tanıtımı, izleyiciye hitap etme ve birlikte yaratmayı teşvik etme olarak belirlenmiştir (Bkz. Şekil 2) (Tarnovskaya, 2017).

Şekilde gösterilen üç aşamanın her birinde marka içeriğinin temel özellikleri belirlenmiştir. Kişisel markayı oluşturmanın ilk aşamasında söz konusu kişinin net bir marka profiline sahip olması ve ona sadık kalması esastır. Kişisel marka profili, YouTuber'ın kişiliği, ses tonu, ortam ve marka gibi unsurları içermektedir (şekil 8). İçerik profil ile uyumlu olmalı ve izleyicilere net ve tutarlı bir şekilde iletmelidir. Yazar YouTuber'ların markalarını sadece "kendileri olmak" şeklinde yaratmadıklarını, plan- 
lanmış stratejik kararlarla, açık bir kimlik vasıtasıyla (Arruda, 2005) yarattıklarını ve bu yüzden de birey markaları ile ürün markaları arasında yakın paraleller (de Chernatony ve McDonald, 2003) oluşturduklarını belirtmiştir.

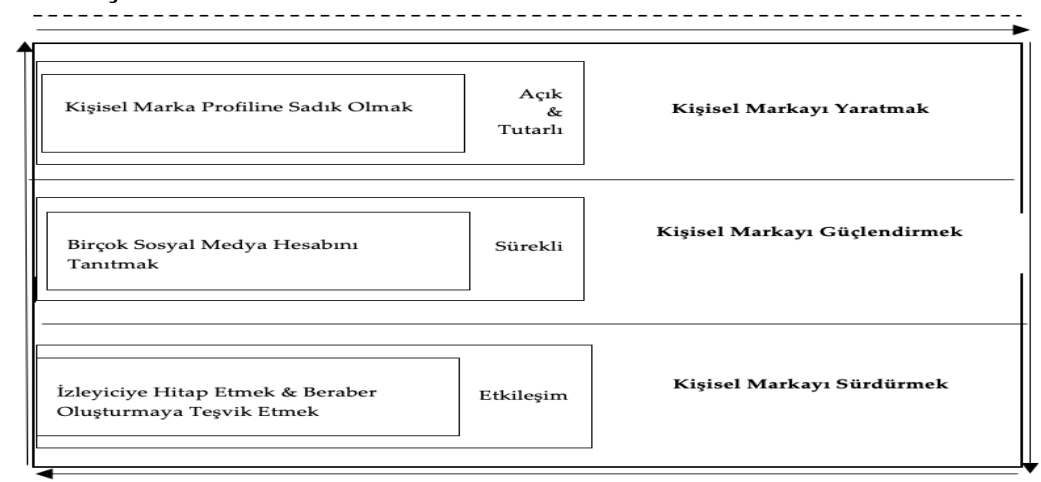

Şekil 2. Sosyal Medyada Kişisel Markalaşmanın Aşamalarn ve TemelÖzellikleri

Kaynak: Tarnovskaya, V. (2017). Reinventing Personal Branding Building a Personal Brand through Content on YouTube, Journal of International Business Research and Marketing, 3(1), 29-35. doi: /10.18775/jibrm.1849-8558.2015.31.3005

Bununda ötesinde YouTuber'lar sosyal ağlarına ve kültürel bilgi denetimlerine yatırım yaparak (Khedher, 2015) diğer insanlardan farklılaşma olasılıklarını arttırmaktadır. Kimliği oluşturmayı kolaylaştıran diğer unsurların yanında, özgünlük yaratmak, kişisel hikaye ve kişilik özelliklerinin ifşa edilmesiyle temin edilmektedir. Özgünlük her ne kadar kimi yazarlara göre (Fournier ve Avey,2011; Barwise ve Meehan, 2010) başarılı bir online markalaşma için kritik faktör olarak vurgulansa da, kimi yazarlar (Chen, 2013; Shepherd,2005) markalaşmada bu tür bir özgünlüğün diğer bireyler tarafından manipüle edilebileceğini belirtmektedirler (Tarnovskaya, 2017).

Yazarın belirlediği kişisel markalamayı güçlendirmenin ikinci aşaması, söz konusu markanın görünürlügünü artırmak için birden fazla sosyal medya hesabı aracılığıyla tanıtılmasını içermektedir. YouTube, Twitter, Facebook gibi sosyal ağlarda hedef kitleyi sürekli maruz bırakmak, ürün markalarının hedef kitlelerinin akılda kalmasını sürdürme çabalarına benzetilmektedir (Holt, 2016; Tarnovskaya, 2017).

Kişisel markayı oluşturmanın üçüncü ve son aşamasında, yeni içeriğin birlikte oluşturulmasını teşvik etmek için izleyicilerle yakın ve kişisel 
etkileşimler geliştirmek ve sürdürmek gerekmektedir. Bu aynı zamanda kişisel markaların hedef kitleleriyle bağıntılı kalması için de önemlidir (Tarnovskaya, 2017).

Son olarak farklı bir bakış açısıyla Rangarjan ve çalışma arkadaşları (2017) sözkonusu farklılıklara rağmen temel kişisel markalaşma sürecinin bazı açılardan ürün ve işletme markalaşma sürecine benzediğinin altını çizmektedir. Yazarlara göre kişisel markalaşma süreci ön analizle başlamaktadır. (Bkz. Şekil 3). Kişi neye değer verdiğini, hangi konularda iyi ve iyi olmadığını belirleyerek kendi temel değerleri, yetkinlikleri ortaya koyar ve misyon ve vizyonunu tanımlar. Benzer şekilde, kar amacı güden ya da gütmeyen kuruluşlar da kurumsal değerler ve yeteneklerini gelecekteki kendi gelişimlerine rehberlik edecek şekilde kullanarak markalaşmayı inşa ederler (Rangarajan vd., 2017).

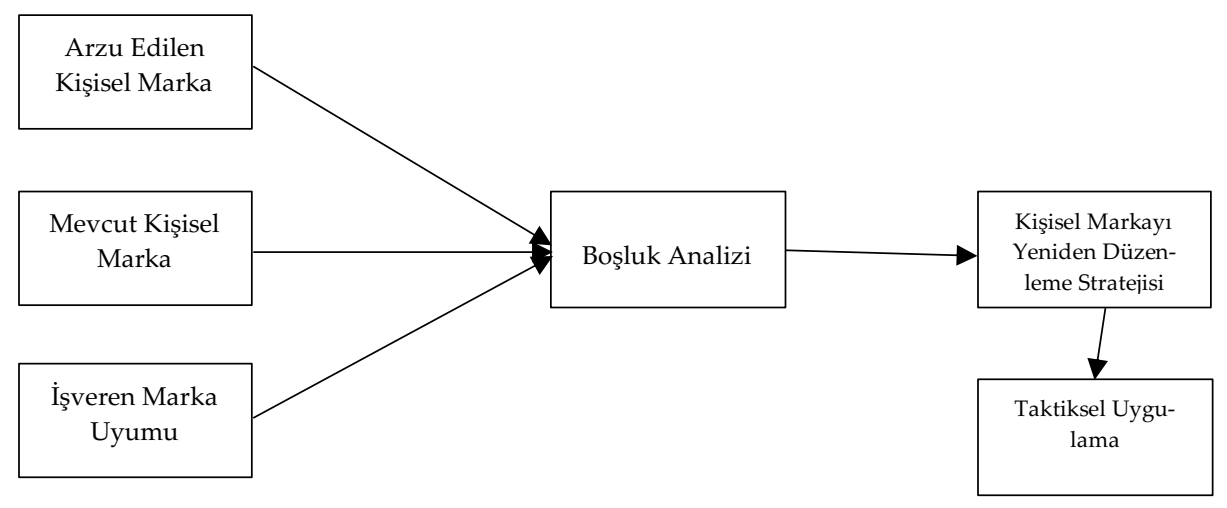

Şekil 3. Kişisel Marka Yaratmak

Kaynak: Rangarajan, D. and Gelb, B. D. ve Vandaveer, A. (2017). Strategic Personal Branding-And How It Pas Off. Business Horizons, 60, 657-666. doi: 10.1016/j.bushor.2017.05.009

Benzer şekilde bir işletmenin ya da ürünün markalaşmasa gibi, kişisel markalaşma süreci de hedef kitleleri ve/veya pazarı dikkate alır. Buradaki önemli faktör, belirli bir kitle için markanın tutarlı olmasıdır. Yazarlara göre işletme markasındaki kişisel markalaşmanın bir sonraki adımı, bir kişinin markasını şekillendirmek veya revize etmek için vizyonunun ve misyonun ne önerdiğini düşünmek ve ardından istenen markayı o anda nasıl algılandığıyla karşılaştırmayı içermektedir. Burada var olan bir boşluğu bulmak önemlidir. Leland (2016) kişisel markalaşmayı bir dizi 
büyük itici güç olarak değil, bunun yerine sosyal medyayı da içeren ancak bununla sınırlı olmamak üzere devam eden, sürekli bir küçük çaba akışı olarak tanımlamaktadır. Süreç içerisinde önemli bir boşluk yoksa yazarlar, kişinin kişisel markasını izlemesini tavsiye etmektedir. Kişinin yetkinlikleri ve izleyicilerin ilgileri zamanla değişebilir (Rangarajan vd., 2017). Yazarlara göre kişisel markalama sürecinin son adımı, kişisel markayı istenen izleyicilere veya pazar yerlerine gösterecek taktikler tasarlamaktır. Sosyal medya bunun için açık kanallar sunmaktadır. Sosyal ağ vasitasıyla oluşturulacak olan içerikte ilk olarak, kişinin hangi kitleye hangi bilgileri aktarmaya çalıştığı ve hangi duysal bağı kurmaya çalıştığını yanıtlaması gerekmektedir (Rangarajan vd., 2017). Tüm bu aşamalarla birlikle kişisel markalaşma sürecinde oluşturulan marka, saygı ve ilişki inşasında dengede kurulmalı, kurumsal desteklerle kişisel markalaşma güçlendirilmeli, kişisel marka ile işletme markası arasındaki ilişki esnetilmeli ve son olarak kişisel markalar zaman içerisinde ölçülme değerlendirilmeli ve uyarlanmalıdır (Rangarajan vd., 2017). 2019 yılına gelindiğinde kişisel markalaşma konusunda önemli bir yazar olan Khedher, kişisel markalaşma aşamasının (1) marka kimliğini oluşturması, (1) markanın konumlandırılması ve (3) kişisel markanın değerlendirilmesi olarak üç aşamadan oluştuğunu ileri sürmüştür (Bkz. Şekil 4).

Kişisel markalaşma aşaması ilk olarak, kişinin kendini bir rolde tanımladığı özniteliklerinin, inançlarının, değerlerinin, güdülerinin ve deneyimlerinin bir envanterini oluşturmasıyla başlamaktadır (McNallyveSpeak, 2002). Kişisel markalaşma yolunda olan kişiler, hedef pazarın beklenti ve ihtiyaçlarını karışlarken, kendilerini diğerlerinden özellikleri açısından farklılaştırmaları gerekmektedir (Parmentier, 2012). Tanımlanan kişisel özellikler daha sonra karşılaştırılarak, hedef kitlenin ihtiyaç ve beklentisiyle eşleştirilmelidir. Marka kişiliğinin oluşmasında önemli bir faktör olan özdenetim, kişinin hedef pazarını ve rakiplerini tam olarak anlamasına dayanmaktadır. Kişisel marka kimliği, markalanacak kişinin içsel niteliklerinden ve kişinin diğer insanlarla olan ilişkisinden oluşan diş unsurlardan oluşmaktadır (Khedher, 2019).

Yazara göre kişisel markalaşma aşamasının ikinci aşamasında kişi, markasını tüketicinin zihninde konumlandırılması gerekmektedir. Marka konumlandırma, bir kişinin marka kimliğinin belirli bir hedef pazara yönelik aktif pazarlama iletişimi çabalarını ifade eder ve kişisel 
markalaşmada benliğin tanıtımına odaklanır. Bireylerin, hedef kitlesi için değerli olan olumlu özelliklerini vurgulamak ve aynı zamanda kendilerini pazardaki diğer bireylerden farklılaştırmak için marka konumlandırması şarttır. Kişisel markalaşma için marka konumlandırma, kişinin kendisi sunması (Labresque vd., 2011) sözsüz ipuçları (görünüm ve tarz gibi), sözlü açılamalar (benlik hakkında bilgi) yoluyla ortaya çıkmakta ve diğerlerinin kişinin yetkinliğiyle ilgili algılarını şekillendirmektedir (Roberts, 2005; Khedher,2019).

Kişisel markalaşmasının son aşaması kişinin kendi markasını değerlendirmesidir. Yazara göre kişisel markalaşma kişinin kendi imajının kontrolünü ele almasıyla ilgilidir ve tıpkı ürün veya şirket gibi, hedeflenen sonuçlara ulaşmak için kişisel bir marka oluşturulur. Uygulanabilir profesyonel imaj oluşturan kişiler, hedef kitle tarafından amaçlarını gerçekleştirebilecek yetenekte olarak algılanırlar. Kişinin markasında belirttiği hedefler ile hedef kitlenin yargıları arasındaki uyumsuzluk, markalaşma başarısızlığını temsil etmektedir (Labresque vd., 2011). Bir marka, pazarın memnun etmek için oluşturulduğundan bu aşamanın amacı, markalaşma çabalarının markalaşma hedeflerine ve kişisel hedeflere ulaşıp ulaşmadığını belirlemeli bu yüzden hedef kitleden geri bildirim almalıdır (Khedher, 2019).

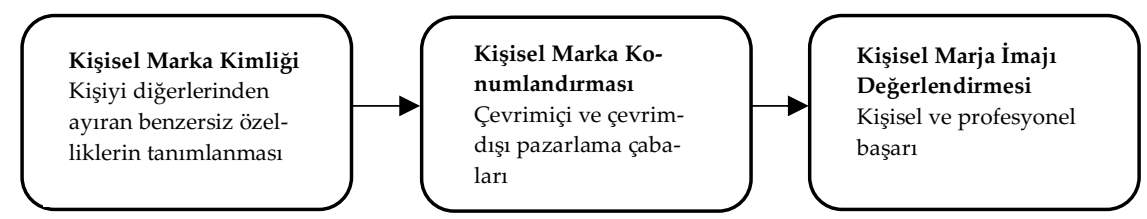

Şekil 4. Kişisel Markalaşma Süreci

Kaynak: Khedher, M. (2019). Conceptualizing and Researching Personal Branding Effects on the Employability, J Brand Manag, 26,99-109

\section{Son Yılarda Kişisel Markalaşma Kavramıyla İlgili Yapıllmış Çalışmalar}

Tüketiciden tüketiciye ulaşan bir bilgi çağına yol açtı̆̆ iddia edilen kişisel markalaşma, birçok yazar tarafından geniş bir şekilde tartışılmıştır (Karaduman, 2013; Kucharska, 2017; Lampel ve Bhalla, 2007; Vitberg, 2009). Konuyla ilgili literatür incelendiğinde, son yıllarda ele alınan en önemli ve temel konuların dijital kişisel markalaşmada dikkat edilmesi 
gereken faktörler, sosyal medyada meydana gelmiş kişisel markaların süreci, kişisel markalaşmada sosyal medya seçimi, farklı meslek gruplarında ve işletmelerde kişisel markalaşmayı etkileyen faktörler, kişisel markalaşmanın istihdam edilebilirlik üzerindeki etkisi, kariyer sürecinde kişisel markalaşmanın öncülleri ve sonuçları ve paydaşların kişisel markalaşma üzerindeki etkisi gibi konuların olduğu görülmektedir.

2013 yılında ilk olarak Chen kişisel markalaşmanın sosyal medya tüketimi (YouTube) içinde nasıl yer aldığını incelemeyi amaçlamıştır. Yazarın elde ettiği sonuçlara göre, söz konusu sosyal medyada marka yaratma süreci, özünü çıkarmak, ifade etmek ve dışarı yaymak olmak üzere üç aşamadan oluşmaktadır. Marka yaratma sürecinin ilk aşaması sosyal medyadaki amatör kişilerin benzersiz bir kişisel marka değeri vaadi yaratan, temel tanımlayıcı niteliklerini ortaya çıkarmak için kendi içlerine baktıkları, en mükemmel davranış ve ideallerini seçip planlayıp sosyal medyaya yükledikleri aşamadır. Sosyal medyada kişisel markalamanın ikinci aşaması olan ifade etme aşamasında, kişiler bir özellik kümesi etrafında ilgi çekici bir kişisel marka beyanı oluşturdukları belirlenmiş ve son aşamada ise çoğu katılımcının dünya çapındaki izleyicilerin ilgisini çekmeye yönelik birincil amaç (markalarını dış dünyada görünür olması) için bir strateji oluşturmayı içerdiği ortaya konmuştur. Bu bağlamda, son dışarı yayma aşamasında katılımcıların farklı strateji benzersiz görüşlerini, becerilerini ya da yeteneklerini geliştirmek ve hedeflerine ulaşmak için çeşitli strateji kombinasyonları planladıkları görülmüştür (Chen, 2013).

Aynı yıl içerisinde Lindahl ve Öhlund ele aldıkları çalışmalarında, kişilerin sosyal medyada imaj yaratma aracılığıyla markalaşma davranışlarını incelemişlerdir. Yaptıkları araştırma sonucunda kişilerin Instagram'da kimliklerinin sadece seçilmiş, incelikli bir kısmını gösterdiklerini ve söz konusu sosyal ağının kişilere kendi kimlikleri ve benlikleri olarak ne ifade etmek istiyorlarsa onu ifade edebilme imkânı konusunda özgürlük verdiği ortaya konmuştur. Kişisel markalaşma açısından sosyal medyada görsellerin metinlerden daha verimli olduğu, başka bir ifade ile görseller aracılığıyla marka kimliği yaratmanın daha etkili olduğu ortaya konmuştur (Lindahl ve Öhlund, 2013).

2015 yılına gelindiğinde Hood ve meslektaşları, dijital kişisel markalaşma sürecinde kişinin karşı tarafa iletmesi gereken en önemli 
yönleri tartışmış ve kişinin arzulanan kişisel markasından sapan herhangi bir şeyin nihai hedefe kolayca zarar verebileceğinden bahsetmişlerdir. Ele aldıkları çalışmalarında, Linkedln kullanıcılarının profillerinde özelliklerini eksik olarak doldurmaları ve profesyonel fotoğraf eklememiş olmaları durumunun, iş veren açısından tercih edilmeme sebeplerinin başında geldiğini vurgulamışlardır. Benzer şekilde Facebook kullanıcılarının profillerinde sorumsuz olarak yorumlanabilecek davranış göstermeleri ya da siyasi veya kişisel görüş paylaşmalarının, bir adayın imajını olumsuz etkileyerek iş adaylığından çıkarılma nedeni olarak sonuçlanacağını belirtmişlerdir (Machaz ve Shokoof,2016).

Nolan (2015) çalışmasında, kar amacı gütmeyen kuruluşlardaki yöneticileri kişisel marka iletişimlerinin kuruluşlarının misyonuyla ne ölçüde uyumlu olduğunu belirlemeyi amaçlamıştır. Çalışmadan elde edilen sonuç neticesinde yazar, söz konusu yöneticilerin sosyal medyada kişisel markalaşmalarında başarılı olabilmeleri içim yönlendirici ilkeler sunulmuştur. Yazara göre ilk olarak, söz konusu kuruluşun, sosyal medyada misyon ifadesini içeren ya da ima eden, sık sık gönderim yapması gerektiğini belirtmiştir. Bunun yanında yönetici, online gönderilerinde şirketteki kendi pozisyonlarının hedef ve gereksinimlerini de dikkate alarak, mesajlarını pozisyonlarıyla ilişkili olacak şekilde şekillendirmelidir. Her ne kadar yöneticinin iş gereksinimleriyle bağlantılı olmasa da, kişisel sosyal medya hesabından gönderi paylaşması, hem yönetici hem de kar amacı gütmeyen kuruluşa fayda sağladığı ortaya konmuştur (Nolan, 2015).

Walker ise 2016 yılında ele aldığı çalışmasında profesyonel sporcuların markalaşma stratejilerini incelemeyi amaçlamıştır. Yarı yapılandırılmış görüşmelerden elde edilen sonuçlar neticesinde, atletik başarı, farklılaşma ve kurumsal sponsorla olan ilişkiler, profesyonel sporcular için kişisel markalaşma geliştirmede en temel strateji konuları olarak belirlenmiştir (Walker, 2016).

Aynı yıl Brems ve meslektaşları (2016) çalışmalarında, 40 gazetecinin Tweet atma davranışını incelemiş ve gazetecilerin kendilerini tanıtmak, kişisel marka yaratmak için sosyal medyayı nasıl kullandıklarını ve hangi durumlarla karşı karşıya olduklarını içerik analizi ile ortaya koymayı amaçlamışlardır. Yapılan araştırmada kişisel markayı oluşturan üç farklı 
unsurun olduğu ortaya konmuştur. Bu unsurlardan biri Tweeter'ın gazeteciler tarafından imajlarını kontrol etmeye çalıştıkları bir sahne olarak ele alınmasıdır. İkinci unsur gazetecilerin söz konusu sosyal ağda iletişim kurdukları izleyicilerdir. Gazeteciler, Tweeter aracılığıyla vatandaştan, diğer gazetecilerden ve profesyonel kişilerden oluşan izleyicilerle iletişim kurarak, aktif olarak konuştukları veya kişisel/profesyonel düşünce süreçlerine dâhil oldukları etkileşimli bir platform olarak kişisel markalarını yönetmektedirler. Araştırma sonucunda, kişisel markanın son ve en önemli unsuru icracı olarak belirlenmiştir. Gazetecilerin kendilerini sunma biçimleri, serbest çalışan ya da mevcut bir iş yerinde çalışan gazeteciler açısından farklılık gösterdiği tespit edilmiştir. Serbest çalışan gazetecilerin Tweeter'ı diğer kullanıcılarla daha sık tartışma içine girerek ve profesyonel olmayan ayrıntıları paylaşarak kullandıkları ortaya konarken, çalışan gazetecilerin ise çalıştıkları kurumun ve meslektaşlarının haberlerini sık sık paylaştığı ve daha sadık bir davranış gösterdikleri ortaya konmuştur. Öte yandan araştırmada, gazetecilerin Tweeter'daki kişisel markalaşma süreçlerinde özellikle gerçekçi yada ön yargılı, kişisel veya profesyonel olmak arasında ve mesajlarını yayınlarken stratejik olarak kendilerini nasıl tanıtacakları konusunda mücadele ettikleri belirlenmiştir (Brems vd., 2016).

Kucharska'nın 2017 yılında yayınladığı makalesinde kullanıcıların bir marka tanımlama eylemi olarak sosyal ağ siteleri arasından nasıl seçim yaptıklarını daha iyi anlamak amaçlanmıştır. Yazar, marka haline gelmiş sosyal paylaşım sitelerinin tüketiciler için gerçek ve sanal dünyada marka tanımlamaları açısından farklılık gösterdiğini sunan bir model geliştirmiştir. Söz konusu model, kişisel markalaşmanın marka kimliğinin planlanmış bir etkisi olduğunu ve sosyal ağlarda marka değeri yaratmada çok önemli bir unsur olduğunu ortaya koymuştur (Kucharska, 2017).

2018 yılına gelindiğinde Amoako ve Opattah farklı bir yaklaşımla, satış gücü üretkenliğini ve performansını artırmak için satış gücü yönetiminin kişisel markalaşma dinamiklerini ve teknoloji bazlı satış araçlarını nasıl güçlendirebileceğini değerlendirmişlerdir. Elde edilen bulgular neticesinde kişisel markalaşmanın, kişilerin satış gücü motivasyonu ve performans kazanımları üzerinde önemli etkisi olduğu ve kişisel markalaşmanın satış gücü performansının tüm belirleyicileri arasında en güçlü bileşen olduğu ortaya konmuştur (Amoako ve Opattah, 2018). 
2019 yılında Gorbatow ve meslektaşları kişilerin kariyer başarısında, kişisel markalamanın öncüllerini ve sonuçlarını incelemeyi amaçlamışlardır. Yaptıkları araştırma sonucunda yazarlar algılanan istihdam edilebilirliğin aracı olduğu durumlarda, kişisel markalaşmanın kariyer memnuniyetine yol açtığını belirlemişlerdir. Bununla birlikte yazarlar, kariyer başarısı özleminin kişisel markalaşmanın en güçlü öngörücüsü olduğunu ve kariyer geribildiriminin kişisel markalaşma niyetiyle negatif ilişkide olduğunu tespit etmişlerdir. Öte yandan çalışmada, kişilerin kariyer öz yeterliliğinin, kişisel markalaşmaları ile olumlu fakat onların kişisel marka niyetiyle olumsuz bir ilişkide olduğu ortaya konmuştur (Gorbatov vd., 2019).

Khedher'in 2019 yılında ortaya koyduğu araştırmada kişisel markalaşmanın istihdam edilebilirliğe nasıl dönüştürülebileceğini dair bir açıklama sunmayı amaçlamıştır. Araştırma sonucunda kişisel markalaşmanın altı boyutu içeren çok boyutlu bir yapı olduğu ortaya konmuştur. Bu boyutlar kültürel sermaye, sosyal sermaye, sözlü öz sunum, aracılı öz sunum, özgünlük ve görünüş olarak belirlenmiş ve söz konusu boyutların mezun kişilere değer katarak, istihdam sonuçlarını şekillendireceği öne sürülmüştür (Khedher, 2019).

Son olarak Dumont ve Ots, 2020 yılında ele aldıkları çalışmalarında paydaşların kişisel markalaşmaya katılımını tümevarımsal olarak incelenmiştir. Elde edilen çalışma neticesinde, kişisel markalaşmanın, paydaşların kişisel markaları detaylandırmak için üç tür kaynak sağlayan bir sosyal uyulama olduğu öne sürülmüştür. Bu kaynaklar maddi kaynaklardan, bilgi kaynaklarından ve sembolik kaynaklardan oluşmaktadır. Maddi kaynaklarda finans, paydaşlara ilişkiyi göstermek için kullanılan giyim ve medya üreticileri tarafından oluşturulan medya içeriği yer almaktadır. Söz konusu kaynaklar, medya içeriğinin üretimi ve yaygınlaştıılması, paydaşlarla görünür ilişki kurulmasını destekleyerek markanın özümsenmesi amacına hizmet etmektedir. İkinci olarak ortaya konan bilgi kaynakları, marka anlatıları ve biçimsel ifadeleri oluşturmak için ihtiyaç duyulan, farklı paydaşlar hakkındaki bilgileri içermektedir. Çalışma bulguları, bu etkileşimler tarafından sağlanan bilgilerin kişisel marka stratejilerinin tasarımını ve dağıtımını yönlendirmede faydalı olduğu ortaya konmuştur. Son kaynak olarak belirlenen sembolik kaynaklar, paydaşlarla olan ilişkilerden ve bu ilişkiden oluşan 
çağrışımların tanıtılmasından oluşmaktadır. Söz konusu kaynak, paydaşların karşılıkları birbirine verdikleri itibarın öneminden ve karşılıklı destek ile itibarın yayılmasını sağlayan sembolik kaynarı içermektedir (Dumont ve Ots, 2020).

\section{Sonuç ve Değerlendirme}

Kişisel marka kişinin benzersiz değerleriyle oluşmaktadır. Kişisel değerlerin ve avantajların farkındalığıyla oluşan genişletilmiş benlik, kişisel marka yaratımı için oldukça önemlidir (Kucharska, 2017). Ortaya konan çalışmalar sonucunda kişisel markalaşmanın yalnızca kişinin eğitimini, becerilerini, ilgi alanlarını ve yeteneklerini teşvik etmemesi aynı zamanda kişinin karakterini, iş ahlakını ve profesyonel imajını desteklemesi gerektiği söylenebilir. Günümüzde kişilerin hayatında sosyal medyanın her yönüyle aktif hale gelmesi şüphesiz kişisel markalaşma sürecinde de önemli bir yere sahiptir. Bu sebeple, dijital mecrada herkese açık olan kişinin profili, fotoğrafları ve gönderileri, kişinin kişisel markasını tamamlamalıdır. Bunun yanında, başarılı bir kişisel markalaşma bireyin dijital dünyada etkili bir şekilde iletişim kurma becerisine sahip olduğu algısını da etkilemektedir. Algının doğru bir şekilde yönetilmesi için kişiler, gerçek karakterlerinin en olumlu özelliklerini yansıtmaya çalışmak için kendi güçlü ve zayıf yanlarının ve hırslarının üzerinde net bir şekilde düşünmelidir. Öte yandan kişisel markalaşmada kişinin kendi ilgi alanına yönelik bir tutkuya sahip olması şarttır. Kişi eğer bir tutkuya sahip değilse ve gerçekten kendini sevmiyorsa hedef kitlenin kendisiyle ilgili algısını başarılı bir şekilde ikna etmesi zorlaşmaktadır (Rampersad, 2008; Machaz ve Shokoof,2016).

Bunların yanında, kişisel markalaşma hem işveren hem de iş adayları için önemli bir kavramdır. Kişisel markalaşma, insanların yaşamlarının ve işlerinin her alanında yeni iletişim teknolojilerinin ortaya çıkışının yası sıra iş gücü piyasasındaki ve işveren-çalışan ilişkisindeki değişikliklere yanıt olarak ortaya çıkmıştır (Vallas ve Christin, 2018). Bu yeni istihdam biçiminde kişisel markalaşma, kişinin profesyonel kimliğini bir araya getirmeyi ve sunmayı amaçlayan uyarlanabilir bir kariyer davranışıdır (Stepherd, 2005; Parmentier vd., 2013; Gioia vd., 2014; Gorbatow vd., 2019). Günümüzde işletmelerin büyük bir kısmı işe alacakları adaylar 
hakkında karar vermek için sosyal medyayı kullanmaktadır. İş verenler tarafından Linkedln ve Facebook gibi sosyal ağların iş adaylarının nitelik ve becerilerini görmek için sıklıkla kullanılması, kişilerin kendi iş imajlarını ve sosyal aktivitelerini bu mecralarda görünür hale getirmesine yönlendirmektedir (Hoods vd., 2015). Bu açıdan bakıldığında kişisel markalaşma değişen ekonomik çevrede, iş adaylarının kendilerini daha etkili, istihdam edilebilir göstermek ve diğerlerinden farklılaşmak için önemli bir vazgeçilmez bir strateji haline gelmiştir. Günümüz rekabet koşullarında, işletmelerin başarılı olabilmesi, çalışanlarının hem işletmeye hem de müşterilere değer katması ile mümkün olmaktadır. Bu sebeple bir kişinin kişisel markasını ve değerini iş hayatında kullanması hem işletme hem de kendi için önemli bir büyümeye yol açmaktadır (Lair vd., 2005; Machaz ve Shokoof,2016).

Başarılı bir kişisel marka yaratmak kişinin hem beşeri, hem sosyal, hem de ekonomik sermayesine katkıda bulunmaktadır. Kişisel markalaşmaya dâhil olan bireyler, sürekli öğrenmeye yatırım yaparak beşeri sermayelerini geliştirirler. Beşeri sermaye insanların eğitim, öğretim ya da diğer faaliyetler aracılığıyla, kendi rekabet potansiyellerini en üst düzeye çıkararak kendilerine yatırım yapmalarıdır. Kendilerini rakiplerinden ayıran benzersiz özelliklere sahip olarak konumlandıran bireyler, alanlarında uzman olarak tanınırlıklarını arttırabilir, itibar ve güven oluşturabilir, kariyerlerini ilerletebilir ve özgüven inşa edebilirler (Montoya, 2002; McNally ve Speak, 2002; Rein vd., 2006; Arruda ve Dixson, 2007; Khedher, 2019). Bunun yanı sıra, kişisel markalaşma literatürü, temelde bireylere sosyal sermayelerini artırmak için bir teknik sunmaktadır. Sosyal sermaye, kişinin ailesiyle, arkadaşlarıyla, iş ve toplumla bireylere bilgi, rehberlik ve destek sağlayabilecek daha geniş temasları içeren geniş bir ilişki ağının ne ölçüde geliştirildiğini yansıtmaktadır. Kişisel markalaşma, kişilerin kamusal imajlarını geliştirmek için yaptıkları yatırımları temsil etmektedir. Şöhret ve özdeşleşme, kişisel marka sahiplerine kredibilite ve statü sağlayarak, görünürlüğü en üst düzeye çıararak ve popülerliği yaratarak başarının bir ölçüsü olabilir (McNallyveSpeak; Rein vd., 2006; Khedher,2019). Öte yandan, kişisel markalar doğru yetiştirilirse, finansal başarı ve ekonomik karlılık sağlamaktadırlar. İnsanlar, benzer istihdam fırsatlarında başkalarıyla rekabet etmek için veya kendi kariyerlerini doğru yönetmek için, kendilerini kişisel marka olarak konumlandırırlar. 
Markalaşmış bireyler, kendileri için daha fazla değer üreterek, istihdam edilebilirliklerini en üst düzeye çıkarıp ve yaşam boyu kazançlarını arttırabilirler (Peters, 1997; Mantoya, 2002; McNallyve Speak, 2002; Arruda ve Dixson, 2007; Khedher,2019).

Derin bir literatür taraması sonucunda, bu çalışmada kişisel markalaşma kavramına ayrıntılı bir şekilde değinilmiştir. Yapılan literatür taraması neticesinde, araştırmalarda kişisel markalaşmanın kimler tarafından nasıl oluşturulabileceği, güçlü bir kişisel markalaşma için gerekli olan bileşenler ve kişisel markalaşma aşamasında nelere dikkat edilmesi gerektiği açıkça ortaya konduğu görülmüştür. Öte yandan mevcut literatürde kişisel markalaşma kavramıyla ilgili bir takım eksiklikler olduğu gözlenmiştir. Bu gözlemden hareketle, gelecekte konuyla ilgili çalışma ve araştırmalara yönelik aşağıdaki öneriler sunulmuştur:

- Literatürdeki araştırmalar incelendiğinde, ilk olarak kişisel markalaşmayla ilgili genelde nitel araştırmaların yapıldı̆̆ı ve nicel araştırmaların neredeyse hiç yapılmadığı görülmüştür. Bu sebeple, gelecekte konuyla ilgili daha fazla nicel araştırmaların yapılması önerilebilmektedir.

- Literatürde kişisel markalaşma değeri kavramına çok az değinildiği görülmüştür. İleriki çalışmalarda kişisel marka değerinin nelerden oluştuğu ve kişisel marka değerinin nasıl ölçülebileceğiyle ilgili araştırmaların yapılması önerilmektedir.

- Literatürde kişisel marka sadakati kavramına hiç değinilmediği görülmüştür. Bu sebeple, kişisel markalara karşı oluşan sadakat kavramı ve sadakatin ölçülmesiyle ilgili çalışmalar gerçekleştirilebilir.

- Kişisel markaların ürün-şirket markaları gibi genişleme stratejileri uygulayıp uygulamadıkları ve söz konusu genişleme stratejilerinin tüketiciler tarafından nasıl algılandığı konusunun gelecek çalışmalarda araştırılması önerilmektedir.

- Kişisel markalara karşı oluşan marka aşkı ve marka nefreti kavramlarının incelenmesi ve olası sonuçlarının araştırılması önerilmektedir.

- UUrün markalarında olduğu gibi kişisel markalarda da oluşan taklit kişisel markaların varlığı ve bunlara karşı tüketicilerin tutum ve algılarının araştırılması önerilmektedir. 


\section{EXTENDED ABSTRACT}

\section{A Literature Review on Personal Branding \\ *

\author{
Melis Kaytaz Yiğit
} \\ Avrasya University}

With the rapid spread of social media, consumer-to-consumer information has become an important role in creating personal awareness, building credibility, promoting personal differentiation and managing the potential for personal branding. A literature review has been conducted to study the development of the concept of personal branding from the past to the present. For this purpose, first, the definition of the concept of personal branding and the changes of the definition were examined. Then, the key components that make up personal brands were created through important studies in the literature, and over the years, the development of definition and the personal branding processes identified by authors were discussed. Finally, the research gaps in the literature have been identified and the research proposals have been made to researchers who want to work on the subject.

The concept of personal branding, first introduced in 1970, involves the individual's self-planned marketing process. In the literature, many writers have touched on the concept of personal branding and shaped the development of the concept. Perception has seen as the common point of the individual branding concepts of these authors. In other words, personal branding has been defined as how others perceive the person and how they appeared by others.

Personal branding is not only related to a person's image and reputation, but also is the key to influencing the environment and future opportunities. In order create a storn personal brand, an individual needs to develop strategies and actions that will guide his or her brand. Current literature exhibits that a strong brand can not exist without originality, leadership skills. Individual's background, adopted philosophy, lifestyle and passion are extremely important in creating personal brand. With these reviews the concept of personal branding in literature is shaped through various components. Some authors have indicated that personal branding 
it composed of components of permanence and goodwill expertise, authority, difference, interest, visibility, while some writers said that the concept is composed of components of being semantic, relevant and consistent.

In addition to these, with literature review it has been seen that various processes and stages on how to create personal brand have been proposed by authors. Although each proposed personal branding stage has different dimentions of its own, it is seen that it has the same logic at its core. The common point of the different self-branding phases proposed by different authors is that the process starts with a preliminary analysis that identifies the individual's own competencies and ambitions. In line with the skills and ambitions defined, a person develops their own brand and communicates their messages in the physical and digital areas where they will present their brand. Literature also underlines the memorability interpersonal interactions and builds concensus that conscious and consistinet management in relationships helps brand awareness. When a personal relationship first provides values for another, brand equity begins to accumulate and the relationship develops into a branded relationship.

On the other side, creating personal brand at online has also addressed in literature. Unlike offline personal branding process, the online personal branding the process determined as sometimes not sequential but runs parallel. The first stage of building online personal branding process as the commitment to the personal brand profile which underlines the essential of the person has a clear brand profile and remains loyal to it. The second phase of strengthening online personal branding involves promoting the brand through multiple social media accounts to increase its visibility. The thisd and final stage of onle personal branding is to develop and maintain close and personal interatims with audiences to encourage co-creation of new content.

Finally, when the studies covered by 10 years have been examined, it is founded to include the most important and key issues in digital personal branding, the process of personal brands that have taken place on social media, social media selection in personal branding, factors affecting personal branding in different trade groups and businesses, the impact of 
personal branding on recruitment, the pioneers and consequences of personal branding in the career process, and the impact of stakeholders on personal branding.

Beside all of these, it has seen that personal branding is also an important concept for both employers and job candidates. It has emerged in response to changes in labor market and employer-employee relationship, as well as the emergence of we communivcation technologies in all aspects of people's lives and businesses. As a result of deep literature review, the concept of personal branding was discussed in detail, observed that there were some gaps in the current literature and some suggestions were presented for future studies and researches.

\section{Kaynakça / References}

Aaker, D.A. (1991). Managing brand equity: Capitalizing the value of a brand name. New York: The Free Press.

Aaker, J. (1997). Dimensions of brand personality. Journal of Marketing Research, 34(3), 347-56. doi: 10.2307/3151897.

Amoako, G. K. ve Okpattah, B. K. (2018). Unleashing salesforce performance: The impacts of personal branding and technology in an emerging market. Technology in Society, 54,20-16. doi: 10.1016/j.techsoc.2018.01.013

Arruda, W. (2005). An introduction to personal branding: A revolution in the way we manage our careers, 10 Ocak 2021 tarihinde https://docplayer.net/20769045-An-introduction-to-personal-branding-a-revolution-in-the-way-we-manage-our-careers.html adresinden alındi.

Arruda, W. ve Dixson. K. (2007). Career distinction, stand out by building your brand. Hoboken: Wiley

Baltezarević, R., ve Milovanovic, S. (2014). Personal branding, proceedings: management, marketing and communication: Current and future trends. Faculty of Business Economics and Entrepreneurship, Belgrad

Barwise, P. ve Meehan, S. (2010). The one thing you must get right when building a brand. Harvard Business Review, 88(1/2), 80-84

Brems, C., Temmerman, M., Graham, T. ve Broersma, M. (2017). Personal branding on Twitter. Digital Journalism, 5(4), 443-459. doi:10.1080/21670811.2016.1176534 
Chen, C. (2013). Exploring personal branding on YouTube, Journal of Internet Commerce, 12(4), 332-347, doi: 10.1080/15332861.2013.859041

de Chernatony, L. ve McDonald, M. (2003). Creating powerful brands: in consumer, service and industrial markets, 3rd ed, Oxford: Elsevier/Butterworth-Heinemann

Dumont, G. ve Ots M. (2020). Social dynamics and stakeholder relationships in personal branding. Journal of Business Research, 106, 118-120. doi: 10.1016/j.jbusres.2019.09.013

Farhana, M. (2012). Brand elements lead to brand equity: Differentiate or die. Information Management and Business Review, 4(4), 223-233. doi: 10.22610/imbr.v4i4.983

Fournier, S. ve Avery, J. (2011). The uninvited brand. Business Horizons, 54, 193 - 207. doi: 10.1016/j.bushor.2011.01.001

Gioia, D. A., Hamilton, A. L. ve Patvardhan, S. D. (2014). Image is everything. Res. Organ. Behav. 34, 129-154. doi: 10.1016/j.riob.2014.01.001

Gorbatow, S., Khapova, S. N. ve Lysova, E. I. (2019). Get noticed to get ahead: the impact of personal branding on career success. Front. Psychol.10,113 doi: 10.3389/fpsyg.2019.02662

Harris, L., ve Rae, A. (2011). Building a personal brand through social networking. Journal of Business Strategy, 32(5), 14-21. doi:10.1108/02756661111165435.

Holt, D. (2016). Branding in the age of social media. Harvard Business Review, 40-50 https://hbr.org/2016/03/branding-in-the -age-of-social-media.

Hood, K. M., Robles, M., ve Hopkins, C. D. (2015). Personal branding and social media for students in today's competitive job market. The Journal of Research in Business Education, 56, (2), 33-47. https://search.proquest.com/openview/2ad094d25e395f75e82fb913c34d00c4/1?pq-origsite=gscholarvecbl $=34490$

Johnson, C. (2019). Platform: The art ve science of personal branding. New York: Lorena Jones Books.

Kang, K. (2013). Branding pays. Palo Alto: Branding Pays Media.

Kapferer, J.N. (2004). The new strategic brand management: Creating and sustaining brand equity long term. London: Kogan Page.

Karaduman, İ. (2013). The effect of social media on personal branding efforts of top level executives. Procedia-Social and Behavioral Sciences, 99, 465473. doi:10.1016/j.sbspro.2013.10.515 
Keller, K.L., ve Richey, K. (2006). The importance of corporate brand personality traits to a successful 21st century business. Journal of Brand Management, 14(1-2), 74-81. doi:10.1057/palgrave.bm.2550055.

Khedher, M. (2014). Personal branding phenomenon. Business and Management,6(2),2940.http://ijibm.site666.com/IJIBM_Vol6No2_May2014.pdf\#page=34

Khedher, M. (2015). A brand for everyone: Guidelines for personal brand managing. The Journal of Global Business Issues, 9(1), 19 - 27. doi: 10.1057/s41262-018-0117-1

Khedher, M. (2019). Conceptualizing and researching personal branding effects on the employability, J Brand Manag, 26,99-109.

Kotler, P., ve Armstrong, G. (2012). Principles of marketing, 14th ed. New Jersey: Pearson Prentice Hall.

Kucharska, W. (2017). Consumer social network brand identification and personal branding. How do social network users choose among brand sites?. Cogent Business ve Management, 4(1). doi:10.1080/23311975.2017.1315879

Labrecque, L.I. Markos, E. ve Milne, G. R. (2011). Online personal branding: processes. challenges, and implications. Journal of Interactive Marketing, 25(1), 37-50. doi: 10.1016/j.intmar.2010.09.002

Lair, D. J., Sullivan, K. ve Cheney, G. (2005). Marketization and the recasting of the professional self: The rhetoric and ethics of personal branding. Management Communication Quarterly, 18(3), 307-343. doi:10.1177=0893318904270774

Lampel, J., ve Bhalla, A. (2007). The role of status seeking in online communities: Giving the gift of experience. Journal of Computer-Mediated Communication. 12, 434-455. doi:10.1111/j.1083-6101.2007.00332.x

Leland, K. T. (2016). The Brand mapping strategy: Design, build, and accelerate your brand. Irvine, CA: Entrepreneur Press.

Lindahl, G. ve Öhlund, M. (2013). Personal branding through imagification in social media. Master Thesis of Science in Business and Economics, Stocholm University.

Liu, R., ve Suh, A. (2017). Self-branding on social media: An analysis of style bloggers on Instagram. Procedia Computer Science, 124, 12-20. doi:10.1016/j.procs.2017.12.124. 
Machaz, H., ve Shokoofh, K. (2016). Personal branding: An essential choice. Journal of Multidisciplinary Research, 8(2), 65-70. http://web.a.ebscohost.com/ehost/pdfviewer/pdfviewer?vid=0vesid=553eaf2b-e350463a-8ed8-7de15ea49635\%40sdc-v-sessmgr01

McNally, D. ve Speak, K.D. (2003). Be your own brand. San Francisco: BerrettKoehler Publishers, San Francisco.

Montoya, P. ve Vandehey, T. (2005). The brand called you. Personal Branding Press, Tustin.

Nolan, L. (2015). The impact of executive personal branding on non-profit perception and communications, Public Relations Review, 41, 288-292. doi: 10.1016/j.pubrev.2014.11.001

Olins, W. (2009). Manual de branding [Branding manual]. Bucharest: Vellant.

Ollington, N., Gibb, J. ve Harcourt, M. (2013). Online social networks: An emergent recruiter tool for attracting and screening, Personal Review, 42,(3), 248-265. doi: 10.1108/00483481311320390

Orehek, E. ve Human, J. L. (2017). Self-expression on social media: Do tweets present accurate and positice portraits of impulsivity, self-esteem, and attachment style, Personality and Social Psychology Bulletin, 43(1), 60-70. doi: 10.1177/0146167216675332

Parmentier, M.A., ve Fischer, E. (2012). How athletes build their brand. International Journal of Sport Management and Marketing, 11(1/2): 106-124. doi: 10.1504/IJSMM.2012.045491

Peters, T. (1997). The brand called You. Fast Company, New York.

Philbrick, J. L. ve Cleveland, A. D. (2015). Personal branding: Building your pathway to professional success, Medical Reference Services Quarterly, 34(2), 181-189. doi:10.1080/02763869.2015.1019324

Rampersad, H.K. (2006). The personal balanced scorecard: The way to individual happiness, personal integrity and organizational effectiveness, Information Age Publishing, Conneticut.

Rampersad, H.K. (2008). Authentic personal branding. www.brandchannel.com, New York.

Rangarajan, D. ve Gelb, B. D. ve Vandaveer, A. (2017). Strategic personal branding-and how it pas off. Business Horizons, 60, 657-666. doi: 10.1016/j.bushor.2017.05.009

Rein, I., Kotler, P., Hamlin. M. ve Stoller, M. (2006). High visibility: Transforming your personal and professional brand. 3rd ed. New York: McGrawHill. 
Roberts, L.M. (2005). Changing faces: Professional image construction in diverse organizational settings. Academy of Management Review, 30, 685711. doi: $10.5465 / \mathrm{amr} .2005 .18378873$

Shepherd, I. D. H. (2005). From cattle and coke to charlie: Meeting the challenge of self marketing and personal branding. Journal of Marketing Management, 21, 589-606. doi: 0.1362/0267257054307381

Shuker, L. (2010). It'll look good on your personal statement: A multi-case study of self-marketing amongst 16-19 year olds applying to university. University of Cambridge, UK: Homerton College

Tarnovskaya, V. (2017). Reinventing personal branding building a personal brand through content on YouTube. Journal of International Business Research and Marketing, 3(1), 29-35. doi: /10.18775/jibrm.18498558.2015.31.3005

Vallas, S. P. ve Christin, A. (2018). Work and identity in an era of precarious employment: How workers respond to "Personal Branding" discourse. Work. Occup. 45, 3-37. doi: 10.1177/0730888417735662

Vitberg, A. (2010). Developing your personal brand equity. Journal of Accountancy, 24(1),42-45. https://search.proquest.com/openview/1b5b159a01a2a89b0483ca3001ddb4c6/1.pdf?pqorigsite $=$ gscholarvecbl $=41065$

Vitberg, A. K. (2009). Analog vs. digital personal branding - a new twist on personal marketing plans. CPA Practice Management Forum, 5, 10-13.

Vitelar, A. (2019). Like me: Generation $\mathrm{z}$ and the use of social media for personal branding. Management Dynamics in the Knowledge Economy, 7, 1723-1760. doi:10.25019/mdke/7.2.07

Walker, M. (2015). Personal branding: A Perspective from the professional athlete-level-of-analysis. Int. J. Sport Management and Marketing, 16,(1/2), 112-131. doi: 10.1504/IJSMM.2015.074920

Wilson J.S., ve Blumenthal, I. (2008). Managing brand you: Seven steps to creating your most successful self. New York: AMACOM.

Wee, L. ve Brooks, A. (2010). Personal branding and the commodification of reflexivity. Cultural Sociology, 4(1), 45-62. doi: 10.1177/17499755 


\section{Kaynakça Bilgisi / Citation Information}

Kaytaz Yiğit, M. (2021). Kişisel markalaşma üzerine bir derleme çalışması. OPUS-Uluslararası Toplum Araştırmaları Dergisi, 18(39), 895-928. DOI: 10.26466/opus.846679. 